\title{
Relevant Allelic Frequency of Gene Polymorphism and Genetic Predisposition of Human Papillomavirus in Patients with Cervical Cancer
}

\author{
Reza Mirnejad ${ }^{1}$, Malike Sharif ${ }^{2}$, Nikta Sajjadi ${ }^{3}$, Vahhab Piranfar ${ }^{4}$, Davood Zaeifi
}

1. Molecular Biology Research Centre, Baqiyatallah University of Medical Sciences, Tehran, Iran.

2. Department of Biology, Science and Research Branch, Islamic Azad University, Tehran, Iran.

3. Department of Microbiology, Science \& Research Islamic Azad University, Damghan Branch, Damghan, Iran

4. Department of Microbiology, Islamic Azad University, Tonekabon branch, Tonekabon, Iran.

5. Department of Biology, North-Tehran Branch, Islamic Azad University, Tehran, Iran

\begin{tabular}{c}
\hline KEYWORDS \\
\hline Cervical Cancer \\
Human Papillomavirus \\
Amplification-refractory \\
mutation system \\
p53 gene \\
Single Nucleotide \\
Polymorphisms \\
\hline Article Info
\end{tabular}

Received 2018/06/20;

Accepted 2018/08/07;

Published Online 2018

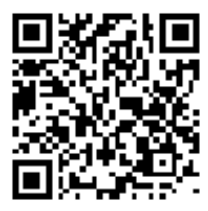

\section{ABSTRACT}

Background and Objectives: The present study investigated the correlation between p53 gene codon 72 polymorphism and 6 other genetic single nucleotide polymorphisms (SNPs) in patients with cervical cancer infected by HPV.

Methods: 450 patients with cervical cancer (280 Squamous cell carcinoma and 170 Adenocarcinoma) were followed at hospitals in Iran from Dec. 2014 to Apr. 2015. Moreover, 100 age/sex-matched was used as the control group. HPV was detected by LINEAR ARRAY® HPV Genotyping Test. Allelic frequency of 6 gene polymorphisms was detected by the amplification-refractory mutation system (ARMS).

Results: From 450 patients, 408 cases $(90.66 \%)$ were positive for HPV. Four genotypes were observed as single infections $(16,18,31$, and 45). The most common genotypes were HPV-16 (73.52\%), HPV-18 (23.28\%), HPV-31 and 45 $(3.17 \%)$, respectively. 306 samples were arginine-arginine homozygous $(70.6 \%$ and $71.4 \%$ of adenocarcinoma and squamous cell carcinoma, respectively), 70 cases were arginine-proline heterozygous (17.6\% of adenocarcinoma and $23.8 \%$ of squamous cell carcinoma), and 20 cases were as proline-proline homozygous ( $11.8 \%$ and $4.8 \%$ of adenocarcinoma and squamous cell carcinoma, respectively).

Conclusion: The prevalence of HPV was $84 \%$ and that was the estimation of the Global Burden among Iranian patients with cervical cancer (85\% - 99\%). There was no correlation between mutations in the p53 allele and the size/type of tumors, while we found a correlation between mutations in p53 alleles and age. Therefore, XRCC1 G399A SNP and TP53 G72C SNP were significantly correlated with the cervical cancer.

Corresponding Information: Vahhab Piranfar, Medical Bacteriology, Department of Microbiology, Islamic Azad University, Tonekabon branch, Tonekabon, Iran. Email: vahab.p@gmail.com Tel: 0098-21-82482654

Copyright $\left({ }_{0}\right.$ 2018. This is an open-access article distributed under the terms of the Creative Commons Attribution-noncommercial 4.0 International License which permit copy and redistribute the material just in noncommercial usages, provided the originalwork is properly cited.

\section{Introduction}

Cervical cancer is the third most common malignant women disease and the second cause of cancer-related death (1). HPV is known as the main (risk) factor of cervical cancer (2). According to a monitoring research study by the WHO, one of the most reported cervical cancers disease is related to HPV. In fact, almost all cases of cervical cancer are associated with HPV (3).

Various types of HPV cause sexually transmitted diseases (4-7). HPV could cause a wide range of lesions from benign wart (papilloma) .(6, 8). The prevalence of infection was reported by $46 \%$ among young women in Europe $(9,10)$. The global spread of cervical cancer is growing increasingly overtime and about 500,000 new cases are identified and reported by the WHO and CDC, annually (11).

A direct relationship is approved between cervical cancer and HPV infection. The virus genome products (proteins E1 and E6) are important factors, causing a normal cell transformation change into a malignant transformation. It also causes chromosomal aberration in the cervical epithelial cells, which is effective in the increase of the cervical cancer (12). However, more than 80 types of HPV have 
been identified, among which some types $(16,18$, $33,35,45,51$, and 56) cause cancerous lesions. After the incubation period of infection (1-4 year), nearly $16 \%$ of lesions progressed towards malignant lesions $(13,14)$.

It seems that the main changes involve mutation in tumor suppressor genes in the cervical cell line (15). "Genetic polymorphisms of tumor suppressor genes might be related to the persistence of HPV and its progression to cancer" $(16,17)$. For example, the TP53 suppressor gene is responsible to inactive the HPV protein oncogenic potentiality (18). TP53 is one of the major tumor suppressor genes, which plays a key role in cancer. This gene is located on the short arm of chromosome 17 (17p13.1) with 11 exons and the length of $20 \mathrm{~kb}$ (19). Polymorphisms of the p53 gene are reported in both coding and non-coding regions (20). At least 37 polymorphisms are known that only one of them could change the p53 protein amino acid sequence (21). One of the clear changes is proline convert to serine at codon 47 and another is the change of proline to arginine $(\mathrm{C}$ to $G$ ) in the region of codon 72. Storey and his team (22) found a correlation between the majority of alleles, an arginine $(\mathrm{G})$ form of $\mathrm{p} 53$, and the cervical cancer development. In addition, his reports indicated that this genotype is more susceptible to HPV E6-mediated degradation. Recently, polymorphism is common and causes coding for three genotypes, namely homozygous arginine (Arg-Arg), heterozygous (Arg-Pro), and homozygous proline (Pro- Pro) (22, 23). Moreover, on the molecular level, XRCCl (X-ray cross-complementing group 1) is another gene which is involved in the DNA repair. Arg399Gln genotype is a base excision repair gene XRCCl located on exon 10 , which is a specialized site for DNA repairing function (24).

These polymorphisms are linked with high risk of many other cancers, including lung, mouth, prostate, and colorectal and could be considered as the markers for the cervical cancer (25). Therefore, the aim of this study was to investigate the correlation between HPV relevant allelic frequency of p53 gene codon 72 polymorphism and genetic predisposition of 6 other SNPs to cervical cancer in Iranian women during two years of 2014-2015. In addition, polymorphism in CDKN1A (p21) codon 31, ATM codon 1853, XRCC3 codon 241, TGFB1 codon 10, XRCC1 codon 399, HDM2 promoter 309, could be compared with HPV infection to be introduced as new cervical cancer markers.

\section{Materials and Methods}

\section{1. Study population}

In this cross-sectional study, overall, 450 samples collected from patients who were selected from Shohada Tajrish, Mehrdad, Imam Khomeini, Firoozgar hospitals (in Tehran, Iran) Kamali Hospital (in Karaj, Iran), and Ghaem hospital (in Mashhad, East of Iran) from Dec. 2014 to Apr. 2015

There was no restriction on sample collection in histological type of cervix cancer among patients (adenocarcinoma, squamous cell carcinoma, etc.). Tumor samples were collected from paraffin-shaped embedded tissues by the expert oncologists. Demographic data of patients, including age, tumor size, and tumor type were extracted from hospital records of patients.

One hundred Iranian women with no cancer record and HPV infection were selected as the control group. All patients signed an institutionally approved informed consent and the Islamic Azad University Research Ethics Committee approved the study (TIAU \# 1394 0641).

\section{2. Diagnosis of carcinoma and tissue DNA extraction}

Diagnosis of squamous cell carcinoma and adenocarcinoma of the samples was performed by the pathologists. Paraffin removed using the xylenol and DNA was extracted using the Qiagene kit, (Lot No: 1187253, 4 Cat No: 51306) and its purity was examined by the biophotometer machine (Eppendorf, Hamburg, Germany) at a wavelength of 260-280 $\mathrm{nm}$. To remove RNA contamination, Ribonuclease was used during the extraction process.

\section{3. HPV detection and genotyping}

This study was carried out based on the LINEAR ARRAY® HPV Genotyping Test (Roche Diagnostics GmbH, Penzberg, Germany), 
which includes four main processes of DNA extraction, PCR amplification, hybridization of amplified products to oligonucleotide probes, and colorimetric determination. This test is capable of detecting and genotyping 37 HPV DNA genotypes at the same time $[6,11,16,18,26,31,33,35,39$, $40,42,45,51,52,53,54,55,56,58,59,61,62$, 64, 66, 67, 68, 69, 70, 71, 72, 73 (MM9), 81, 82 (MM4), 83 (MM7), 84 (MM8), 89 (CP6108) and IS39] (26).

The test consists of human $\beta$-globin gene, as an internal control to show the capability of the sample. According to the manufacturer, detection specificity was 99\% (95\% CI: 98-100\%) and detection sensitivity was $96 \%$ (95\% CI: 92-98\%). The PCR reaction conditions were provided with the test kit. Positive reactions produced colored bands (blue) on the test strip. The strips were interpreted using the HPV reference guide provided with the kit. If no HPV band was detected after at least three repeated tests, results were considered negative.

\section{4. P53 gene codon 72 polymorphism and SNP detection by ARMS-PCR}

After HPV detection step, ARMS-PCR designed in order to investigate the p53 gene codon 72 polymorphism in patients, by proline allele F:(5'-GCCAGAGGCTGCTCCCCC-3'), R:(5'-CGTGCAAGTCACAGACTT-3') 177 bp and Arginine allele F:(5'TCCCCCTTGCCGTCCCAA-3'), R:(5'CTGGTGCAGGGGCCACGC-3') with 141 bp (27). Therefore, seven primers were used for the selected SNPs by the ARMS-PCR (28, 29). Related DNA segments were amplified by the thermal cycling $\left(95^{\circ} \mathrm{C}\right.$ for $15 \mathrm{~min}, 39$ rounds of $95^{\circ} \mathrm{C}$ for $1 \mathrm{~min}, 56{ }^{\circ} \mathrm{C}$ for $1 \mathrm{~min}$, and $72{ }^{\circ} \mathrm{C}$ for $1 \mathrm{~min}$ and final extension at $72{ }^{\circ} \mathrm{C}$ for $7 \mathrm{~min}$ ) using QIAGEN HotStart Taq DNA polymerase (Qiagen, Munich, Germany) (28). Relevant segments of Arg SNP were amplified by the thermal cycling $\left(95^{\circ} \mathrm{C}\right.$ for $5 \mathrm{~min}, 30$ cycles of

$45 \mathrm{sec}$ at $95{ }^{\circ} \mathrm{C}, 40 \mathrm{sec}$ at $61{ }^{\circ} \mathrm{C}, 45 \mathrm{sec}$ at 72 ${ }^{\circ} \mathrm{C}$ and final extension at $72{ }^{\circ} \mathrm{C}$ for $5 \mathrm{~min}$ ) and for the Proline SNP amplification, the program was setup at $\left(95^{\circ} \mathrm{C}\right.$ for $5 \mathrm{~min}, 30$ cycles of $45 \mathrm{sec}$ at 95

Vol. 1 No.2 Summer \& Fall 2018
${ }^{\circ} \mathrm{C}, 40 \mathrm{sec}$ at $55{ }^{\circ} \mathrm{C}, 45 \mathrm{sec}$ at $72{ }^{\circ} \mathrm{C}$ and final extension at $72{ }^{\circ} \mathrm{C}$ for $5 \mathrm{~min}$ ). In addition, PCR reaction mixture was used, including $2.5 \mu \mathrm{l}$ of $10 \times$ PCR buffer, $1.5 \mu 1 \mathrm{MgCl}_{2}$ (50 mM), $0.5 \mu 1$ dNTPs $(10 \mathrm{~m} \mathrm{M}), 1.25 \mu \mathrm{l}$ of each primer, $0.5 \mu \mathrm{l}$ of Taq DNA polymerase $(5 \mathrm{U} / \mu \mathrm{l}), 16 \mu \mathrm{l}$ sterile distilled water, and 150-200 ng template DNA in 25 microlitter volume to each reaction.

The human beta-globin gene was used as an internal control to ensure the presence of DNA in the PCR reactions. All reactions were done with Corbett: Rotor-gene 6000 LightCycler. PCR products were analyzed by agarose gel electrophoresis on $2 \%$ agarose gel for $45 \mathrm{~min}$ in $1 \mathrm{X}$ TBE buffer and visualized by ethidium bromide staining.

Amplified fragment was purified by High Pure PCR Product Purification Kit (Macrogen Inc. Seoul Korea). The purified PCR products were sent to Bioneer Company (South Korea) for sequencing. The sequences were aligned through multiple alignments by using Bio Edit software with Clustal W. Nucleotide sequences were compared with each other using MEGA 5 software (The Biodesign Institute, USA). The SNPs were genotyped using SeqManII sequence analysis software (DNASTAR Inc.).

\section{6. Statistical analysis and ethical considerations}

Data were coded without an identifiable personal data. HPV status was compared between the patients in age groups. Descriptive statistics were computed for all variables and reported as means and standard deviations (SDs) for continuous variables or frequencies and percentages for categorical variables. The correlation between demographic data, clinical and laboratory findings, indices and each of their provenances was assessed using the Pearson's chisquare test. Mann-Whitney $U$ test was also performed when applicable. $P$-value less than $0.05 \%$ was considered significant. Statistical analysis was carried out using the SPSS version 16, (Inc., Chicago, IL, USA).

\section{Results}

\section{1. Distribution samples and clinical data}

MODERN MEDICAL LAB JOURNAL 
This paper was a cross-sectional study with Non-Probability Sampling. Normal controls had a similar demographic distribution and a common socioeconomic and age range ( 25 to $82,53 \pm 0.5$ ). Patients with cervical cancer were studied in three age groups: < 35, 35-55 and >55 years (minimum age was under 35 years old and maximum age was over 55 years old). The FIGO stage of cancer ranged between IA2 and IVA, but most patients $(\mathrm{n}=238)$ had stage II/III disease. By histology, 335 patients had squamous cell carcinoma, while 115 had adenocarcinoma of the cervix. Demographic details are shown in Table 1.

\section{2. Genotyping by LINEAR ARRAY® HPV Genotyping Test}

408 cases $(90.66 \%)$ were HPV positive. Four genotypes present single infections $(16,18,31$, 45). The most common genotypes were HPV-16 (73.52\%), HPV-18 (23.28\%), HPV-31, and 45 (3.17\%), respectively. Single infections data are shown in Table 1. HPV-16 and HPV-18, HPV-16 and HPV-31, HPV-16 and HPV-45 were found as double infections. HPV-18 and HPV-31, HPV-18 and HPV-45 were not detected as double infections.

Table 1. Distribution and frequency of single infections HPV virus. Detected by LINEAR ARRAY® HPV Genotyping Test.

\begin{tabular}{|c|c|c|c|c|c|c|c|c|}
\hline \multicolumn{2}{|c|}{ Variable } & \multirow{2}{*}{ 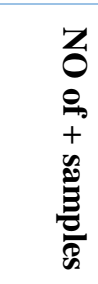 } & \multicolumn{2}{|c|}{ HPV16+ } & \multicolumn{2}{|c|}{ HPV18+ } & \multicolumn{2}{|c|}{ HPV 31+,45+ } \\
\hline & & & 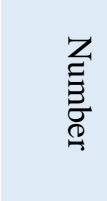 & 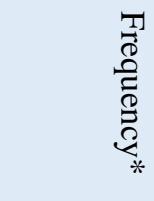 & $\begin{array}{l}Z \\
\Xi \\
\Xi \\
\stackrel{\Xi}{\Xi}\end{array}$ & 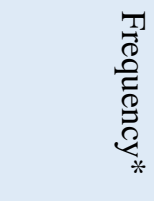 & $\begin{array}{l}Z \\
\Xi \\
\Xi \\
\Xi \\
\varrho\end{array}$ & 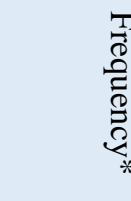 \\
\hline \multirow[t]{4}{*}{ Age groups (yr) } & Under 35 & 56 & 56 & 13.72 & 0 & 0 & 1 & 0.24 \\
\hline & $35-55$ & 112 & 60 & 14.70 & 20 & 4.9 & 2 & 0.49 \\
\hline & Over 55 & 240 & 184 & 45.09 & 75 & 18.38 & 10 & 2.45 \\
\hline & Total & 408 & 300 & $\sim 73.52$ & 95 & $\sim 23.28$ & 13 & $\sim 3.17$ \\
\hline \multirow[t]{3}{*}{ Tumor size } & Under $5 \mathrm{~cm}$ & 337 & 240 & 58.82 & 12 & 2.94 & 9 & 2.20 \\
\hline & Over $5 \mathrm{~cm}$ & 71 & 60 & 14.70 & 83 & 20.34 & 4 & 0.98 \\
\hline & Total & 408 & 300 & $\sim 73.52$ & 95 & 23.28 & 13 & $\sim 3.17$ \\
\hline \multirow[t]{3}{*}{ Type of tumor } & Adenocarcinoma & 113 & 86 & 21.07 & 37 & 9.06 & 1 & 0.24 \\
\hline & Squamous & 295 & 214 & 52.45 & 58 & 14.21 & 12 & 2.94 \\
\hline & Total & 408 & 300 & $\sim 73.52$ & 95 & 23.28 & 13 & $\sim 3.17$ \\
\hline
\end{tabular}

$*$ Frequency $(\%)=(\mathrm{HPV}+$ in each group $\times 100) \div(408$ cases were positive for HPV $)$

\section{3. P53 gene codon 72 (p53c72) polymorphism}

Figure 1 illustrates the agarose gel electrophoresis image used for the amplification of P53 alleles. Totally, 306 samples $(75.00 \%)$ were arginine-arginine homozygous (72.6\% and $27.40 \%$ with adenocarcinoma and squamous carcinoma, respectively), 74 cases (18.13\%) were arginineproline heterozygous $(42.85 \%$ and $57.15 \%$ with adenocarcinoma squamous carcinoma respectively), and 28 cases $(6.86 \%)$ were determined as proline-proline homozygous
$(25.9 \%)$ and $74.1 \%$ with adenocarcinoma tumor and squamous cell carcinoma respectively). 25

heterozygote genotype samples $(6.12 \%)$ contained both Arg and Pro bands. Table 2 shows a detailed analysis of the distribution of P53c72 alleles, genotypes for the control group and HPV positive samples. 


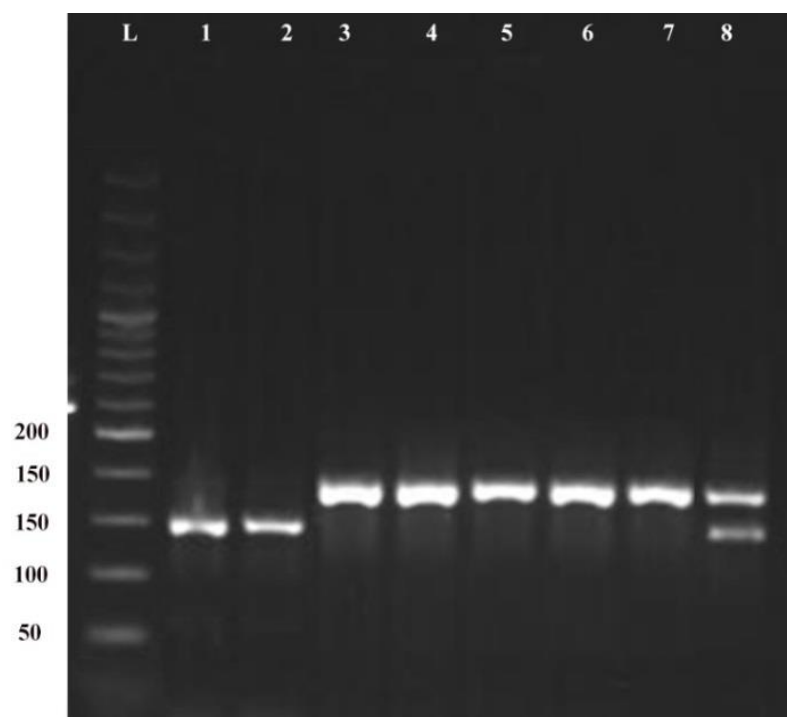

Figure 1. Gel electrophoresis of PCR product of arginine allele and proline allele-specific p53c72. Line L: Ladder 50 bp, Line 1, 2: arginine allele amplification, Line 3-7: Proline allele amplification, Lane 8: heterozygote genotype contained both Arg and Pro bands.

Table 2. The distribution frequency of codon 72 in the p53 gene and controls

\begin{tabular}{cccccc} 
HPV & Classification & number of samples & Arg/Arg $(\%)$ & Arg/Pro(\%) & Pro/Pro(\%) \\
\hline HPV16+ & High risk & 300 & $210(70.00)$ & $70(23.33)$ & $20(6.66)$ \\
\hline HPV18+ & High risk & 95 & $90(94.73)$ & $4(4.21)$ & $1(1.05)$ \\
\hline HPV31+ & High risk & 9 & $5(55.55)$ & $0(0)$ & $4(44.44)$ \\
\hline HPV45+ & High risk & 4 & $1(25)$ & $0(0)$ & $3(75)$ \\
\hline Total & - & 408 & $306(75.00)$ & $74(18.13)$ & $28(6.86)$ \\
\hline Control & - & 100 & $63(63)$ & $20(20)$ & $17(17)$ \\
\hline
\end{tabular}

\section{4. Other polymorphic variations}

Genetic polymorphic variation was determined in candidate SNPs for 408 cervical cancer patients. In addition, 100 females with the same age and with no cancer record were selected as the control group. The two SNPs, HDM2 rs11177386 and LIG4 rs2232641 were all majority alleles, which were omitted from the analysis. Cancer predisposition study showed a significant relationship between XRCC1 G399A and TP53 G72C with cervical cancer (Table 3). Patients harboring the variant allele (A, Gln) had about two times the increased risk of developing cervical cancer $(P=0.02)$.

Table 3. Genotypes and alleles frequencies of seven assessed polymorphisms in 408 cervix carcinoma patients in addition to 100 age-and-gender-matched control volunteers without cancers

\begin{tabular}{|c|c|c|c|}
\hline $\begin{array}{l}\text { Gene, genotype and } \\
\text { allele }\end{array}$ & $\begin{array}{c}\text { Cancer patients' frequency } \\
\qquad(\%, n=408)\end{array}$ & $\begin{array}{l}\text { Normal volunteers' frequency } \\
\qquad(\%, n=100)\end{array}$ & $P$ - Value \\
\hline \multicolumn{4}{|c|}{$C D K N 1 A(p 21)$ codon $31 \mathrm{C}>\mathrm{A}$ Ser/Arg rs 1801270} \\
\hline $\mathrm{C} / \mathrm{C}$ & $278(68)$ & $58(58)$ & \\
\hline $\mathrm{C} / \mathrm{A}$ & $122(30)$ & $30(30)$ & 0.69 \\
\hline $\mathrm{A} / \mathrm{A}$ & $4(1)$ & $0(0)$ & 0.74 \\
\hline $\mathrm{C}$ & $326(80)$ & $89(89)$ & \\
\hline A & $82(20)$ & $15(15)$ & 0.90 \\
\hline \multicolumn{4}{|c|}{ ATM codon $1853 \mathrm{G}>\mathrm{A}$ Asp/Asn rs 1801516} \\
\hline $\mathrm{G} / \mathrm{G}$ & $367(90)$ & $90(90)$ & \\
\hline $\mathrm{G} / \mathrm{A}$ & $8(8)$ & $15(15)$ & 0.37 \\
\hline $\mathrm{A} / \mathrm{A}$ & $2(2)$ & $0(0)$ & 0.16 \\
\hline
\end{tabular}




\begin{tabular}{|c|c|c|c|}
\hline $\mathrm{G}$ & $188(94)$ & $78(78)$ & \\
\hline A & $12(6)$ & $10(10)$ & 1 \\
\hline \multicolumn{4}{|c|}{ TP53 (p53) codon 72 G>C Arg/Pro rs 1042522} \\
\hline $\mathrm{G} / \mathrm{G}$ & $82(20)$ & $10(10)$ & \\
\hline $\mathrm{G} / \mathrm{C}$ & $235(58)$ & $50(50)$ & 0.57 \\
\hline $\mathrm{C} / \mathrm{C}$ & $90(22)$ & $0(0)$ & 0.0087 \\
\hline G & $200(49)$ & $90(90)$ & \\
\hline $\mathrm{C}$ & $208(51)$ & $50(50)$ & 0.84 \\
\hline \multicolumn{4}{|c|}{ XRCC3 codon $241 \mathrm{C}>\mathrm{T}$ Thr/Met rs861539 } \\
\hline $\mathrm{C} / \mathrm{C}$ & $184(45)$ & $20(20)$ & \\
\hline $\mathrm{C} / \mathrm{T}$ & $180(44)$ & $40(40)$ & 0.79 \\
\hline $\mathrm{T} / \mathrm{T}$ & $45(11)$ & $12(12)$ & 0.05 \\
\hline $\mathrm{C}$ & $273(67)$ & $60(60)$ & \\
\hline $\mathrm{T}$ & $135(33)$ & $40(40)$ & 0.12 \\
\hline \multicolumn{4}{|c|}{ TGF $\beta 1$ codon $10 \mathrm{~T}>\mathrm{C}$ Leu/Pro rs 1982073} \\
\hline $\mathrm{T} / \mathrm{T}$ & $196(48)$ & $42(42)$ & \\
\hline $\mathrm{T} / \mathrm{C}$ & $126(31)$ & $40(40)$ & 0.77 \\
\hline $\mathrm{C} / \mathrm{C}$ & $86(21)$ & $21(21)$ & 0.42 \\
\hline $\mathrm{T}$ & $261(64)$ & $56(56)$ & \\
\hline $\mathrm{C}$ & $151(37)$ & $41(41)$ & 0.26 \\
\hline \multicolumn{4}{|c|}{ XRCC1 codon 399 G>A Arg/Gln rs 25487} \\
\hline $\mathrm{G} / \mathrm{G}$ & $212(52)$ & $60(60)$ & \\
\hline G/A & $139(34)$ & $40(40)$ & 0.90 \\
\hline $\mathrm{A} / \mathrm{A}$ & $57(14)$ & $0(0)$ & 0.0007 \\
\hline $\mathrm{G}$ & $282(69)$ & $81(81)$ & \\
\hline A & $126(31)$ & $22(22)$ & 0.02 \\
\hline \multicolumn{4}{|c|}{ HDM2 promoter $309 \mathrm{~T}>\mathrm{C}$ rs 2279744} \\
\hline $\mathrm{T} / \mathrm{T}$ & $122(30)$ & $30(30)$ & \\
\hline $\mathrm{T} / \mathrm{C}$ & $188(46)$ & 43 (43) & 0.86 \\
\hline $\mathrm{C} / \mathrm{C}$ & $98(24)$ & $30(30)$ & 0.44 \\
\hline $\mathrm{T}$ & $216(53)$ & $52(52)$ & \\
\hline $\mathrm{C}$ & $192(47)$ & $50(50)$ & 0.42 \\
\hline
\end{tabular}

\section{Discussion}

Cervical cancer is the second most common cancer among women. HPV and DNA polymorphisms in tumor suppressor genes have been implicated as an etiology of the cervical cancer by the present study and other research studies (30-35).

According to the comparison between the casecontrol group and the patient group in this study, HPV is identified as the major cause of neoplasia development and malignancy in the genital epithelium among hospital infections, especially in patients with persistent infection. There is a great correlation between cervical cancer and some types of HPV (36). More than $90 \%$ of HPV (DNA) genome that leads to the cervical cancers has been detected by the molecular methods (37). The incidence of this cancer is varied concerning

the geographic conditions and environmental and racial factors (38).

In this study, the prevalence rate of HPV infection is higher than the estimated worldwide range $(85 \%)$ among Iranian cervical cancer patients (39). Results of the present study showed that the infection rate of HPV in Iran is lower than North Africa and other Middle East countries with 98\% of positive cases (with preinvasive and invasive lesions). (40).

Khorasanizadeh's study showed a lower prevalence $(76 \%)$ in Iran than this study (33). In 
addition, according to Shahsiah's report patients with HPV-16 and HPV-18 prevalence were $75 \%$ and $18.3 \%$ respectively, while our study reported $90.66 \%$ (41). Perhaps the variety of clinical specimens is a reason for a lower prevalence report in Khorasanizadeh's study and Shahsiah's report. Besides, this rate of percentage in the present study is slightly higher than the prevalence observed in Europe (76\%), North America, Australia (74 to $77 \%$ ), and worldwide $(70.9 \%$ ) $(42,43)$. Therefore, by comparing all data the role of geographical locations and racial factors were established.

Furthermore, age-specific HPV distribution showed a relative increase at older ages among Iranian patients with cervical cancer (more than 55 years old), which is the same as Parlak'study in Turkey. (44).

As it follows, we examined the role of mutation in tumor suppressor genes such as the p53 gene and found that some of these mutations are significantly existed in patients with HPV. The most common mutation of this gene is the conversion of proline to arginine ( $\mathrm{C}$ to $\mathrm{G})$ at codon 72 (45). Our study reported a significant relationship between proline to arginine ( $\mathrm{C}$ to $\mathrm{G})$ polymorphism and patients infected with $\mathrm{HPV}(P$ $\leq 0.05)$. However, the correlation was not significant among mutations in the P53 allele, size $(P=0.741)$ and type of tumor $(P \geq 1)$.

Results indicated that the genetic polymorphism changes could be used as the diagnosis markers or the susceptibility report of cervical cancer. Should both XRCC1 G399A and TP53 G72C mutations are available, the cervical cancer is consequently existed or is about to occur. ( $p \leq 0.05)$. Furthermore, according to the results of seven polymorphisms, open mutation no. 399 (Guanine to adenine) in $X R C C 1$ is individually related to the cervical cancer $(\mathrm{p}=0.0007)$. Mutation in XRCC1 could affect the production of proteins which are essential to the cell cycle regulation. These proteins could reconcile inconsistencies in cell with the help of $\mathrm{p} 53$. This function prevents cancer and uncontrolled growth of cells.

Moreover, Hardy-Weinberg's study indicates an equilibrium in relation to the genotype of the gene. Therefore, deviate from Hardy-Weinberg equilibrium were found for TP53 G72C and XRCC1 G399A SNPs from only in HPV-infected tumors (HWE; $P=0.023-0.071$ ). Accordingly, the combination of HPV and SNPs is reported in cancer predisposition.

The results of this study indicate the high prevalence of this virus among the Iranian women. More than half of the cases were diagnosed with symptoms and were in advanced phases or often untreatable. polymorphism screening is recommended for all women between 20 - 30 years old, annually (46). Moreover, this test is recommended for women aged 30- 65 years infected with HPV. The impact of the polymorphism-screening test is very noticeable in reducing the risk of cervical cancer. If a woman does a TP53 G72C and XRCC1 G399A polymorphism-screening test in her lifetime, the risk of cervical cancer will be decreased. There are more studies that carried out on a larger population and cohort, which confirm the results of the present study.

\section{Conclusion}

SNPs could be a significant biomarker of susceptibility to cervical cancer relationship with HPV infection using the TP53 G72C and XRCC1 G399A polymorphism-screening method. In other words, screening methods are required as the best preventive methods or early detection methods for the cervical cancer in women.

\section{Acknowledgment}

The authors wish to pay special thanks to Dr. Michael J. Misialek, M.D, associate chair of pathology at Newton-Wellesley Hospital and the medical director of the Vernon Cancer Center, who contributed his time and effort to this study.

\section{Conflict of interest}

The authors declare that there is no conflict of interests.

\section{References}

1. Kaarthigeyan K. Cervical cancer in India and HPV vaccination. Indian journal of medical and paediatric oncology : official 
journal of Indian Society of Medical \& Paediatric Oncology. 2012;33(1):7-12.

2. Palefsky JM. Human papillomavirus-related disease in men: not just a women's issue. The Journal of adolescent health : official publication of the Society for Adolescent Medicine. 2010;46(4 Suppl):S12-9.

3. Cutts FT, Franceschi S, Goldie S, Castellsague X, de Sanjose S, Garnett G, et al. Human papillomavirus and HPV vaccines: a review. Bulletin of the World Health Organization. 2007;85(9):719-26.

4. Reitano M. Counseling patients with genital warts. The American journal of medicine. 1997;102(5A):38-43.

5. Turazza E, Lapena A, Sprovieri O, Torres CP, Gurucharri C, Maciel A, et al. Low-risk human papillomavirus types 6 and 11 associated with carcinomas of the genital and upper aero-digestive tract. Acta obstetricia et gynecologica Scandinavica. 1997;76(3):271-6.

6. Palefsky JM, Holly EA, Ralston ML, Arthur SP, Hogeboom CJ, Darragh TM. Anal cytological abnormalities and anal HPV infection in men with Centers for Disease Control group IV HIV disease. Genitourinary medicine. 1997;73(3):17480.

7. Anic GM, Giuliano AR. Genital HPV infection and related lesions in men. Preventive medicine. 2011;53 Suppl 1:S3641.

8. Sugase M, Matsukura T. Distinct manifestations of human papillomaviruses in the vagina. International journal of cancer Journal international du cancer. 1997;72(3):412-5.

9. Adams V, Moll C, Schmid M, Rodrigues C, Moos R, Briner J. Detection and typing of human papillomavirus in biopsy and cytological specimens by polymerase chain reaction and restriction enzyme analysis: a method suitable for semiautomation. Journal of medical virology. 1996;48(2):161-70.

10. Konno R, Paez C, Sato S, Yajima A, Fukao A. HPV, histologic grade and age. Risk factors for the progression of cervical intraepithelial neoplasia. The Journal of reproductive medicine. 1998;43(7):561-6.

11. Nour NM. Cervical cancer: a preventable death. Reviews in obstetrics \& gynecology. 2009;2(4):240-4.

12. Graham SV. Human papillomavirus: gene expression, regulation and prospects for novel diagnostic methods and antiviral therapies. Future microbiology. 2010;5(10):1493-506.

13. Pierce Campbell CM, Messina JL, Stoler MH, Jukic DM, Tommasino M, Gheit $\mathrm{T}$, et al. Cutaneous human papillomavirus types detected on the surface of male external genital lesions: a case series within the HPV Infection in Men Study. Journal of clinical virology : the official publication of the Pan American Society for Clinical Virology. 2013;58(4):652-9.

14. Sundstrom K, Eloranta S, Sparen P, Arnheim Dahlstrom L, Gunnell A, Lindgren A, et al. Prospective study of human papillomavirus (HPV) types, HPV persistence, and risk of squamous cell carcinoma of the cervix. Cancer epidemiology, biomarkers \& prevention : a publication of the American Association for Cancer Research, cosponsored by the American Society of Preventive Oncology. 2010;19(10):2469-78.

15. Senchenko VN, Kisseljova NP, Ivanova TA, Dmitriev AA, Krasnov GS, Kudryavtseva AV, et al. Novel tumor suppressor candidates on chromosome 3 revealed by NotI-microarrays in cervical cancer. Epigenetics. 2013;8(4):409-20.

16. Yang WT, Zheng PS. Promoter hypermethylation of KLF4 inactivates its tumor suppressor function in cervical carcinogenesis. PloS one. 2014;9(2):e88827.

17. Alsbeih G, Al-Harbi N, El-Sebaie M, Al-Badawi I. HPV prevalence and genetic predisposition to cervical cancer in Saudi Arabia. Infectious agents and cancer. 2013;8(1):15.

18. Yim EK, Park JS. The role of HPV E6 and E7 oncoproteins in HPV-associated cervical carcinogenesis. Cancer research 
and treatment : official journal of Korean Cancer Association. 2005;37(6):319-24.

19. Zedan W, Mourad MI, El-Aziz SM, Salamaa NM, Shalaby AA. Cytogenetic significance of chromosome 17 aberrations and P53 gene mutations as prognostic markers in oral squamous cell carcinoma. Diagnostic pathology. 2015;10:2.

20. Pietsch EC, Humbey O, Murphy ME. Polymorphisms in the p53 pathway. Oncogene. 0000;25(11):1602-11.

21. Makni H, Franco EL, Kaiano J, Villa LL, Labrecque S, Dudley R, et al. P53 polymorphism in codon 72 and risk of human papillomavirus-induced cervical cancer: effect of inter-laboratory variation. International journal of cancer Journal international du cancer. 2000;87(4):528-33. 22. Storey A, Thomas M, Kalita A, Harwood C, Gardiol D, Mantovani F, et al. Role of a p53 polymorphism in the development of human papillomavirusassociated cancer. Nature. 1998;393(6682):229-34.

23. Neamatzadeh H, Soleimanizad R, Zare-Shehneh M, Gharibi S, Shekari A, Rahimzadeh AB. Association between p53 codon 72 (Arg72Pro) polymorphism and primary open-angle glaucoma in Iranian patients. Iranian biomedical journal. 2015;19(1):51-6.

24. Yilmaz E, Celik O, Celik E, Turkcuoglu I, Simsek Y, Karaer A, et al. XPD and XRCC1 gene polymorphism in patients with normal and abnormal cervical cytology by pap smear. Eur Rev Med Pharmacol Sci. 2012;16(12):1713-8.

25. Anand $P$, Kunnumakkara $A B$, Sundaram C, Harikumar KB, Tharakan ST, Lai OS, et al. Cancer is a preventable disease that requires major lifestyle changes. Pharmaceutical research. 2008;25(9):2097-116.

26. Alsbeih G, Ahmed R, Al-Harbi N, Venturina LA, Tulbah A, Balaraj K. Prevalence and genotypes' distribution of human papillomavirus in invasive cervical cancer in Saudi Arabia. Gynecologic oncology. 2011;121(3):522-6.
27. Sina M, Pedram M, Ghojazadeh M, Kochaki A, Aghbali A. P53 gene codon 72 polymorphism in patients with oral squamous cell carcinoma in the population of northern Iran. Med Oral Patol Oral Cir Bucal. 2014;19(6):e550-5.

28. Alsbeih G, El-Sebaie M, Al-Rajhi N, Al-Harbi N, Al-Hadyan K, Al-Qahtani S, et al. Among 45 variants in 11 genes, HDM2 promoter polymorphisms emerge as new candidate biomarker associated with radiation toxicity. 3 Biotech. 2014;4(2):13748.

29. Al-Hadyan KS, Al-Harbi NM, AlQahtani SS, Alsbeih GA. Involvement of single-nucleotide polymorphisms in predisposition to head and neck cancer in Saudi Arabia. Genetic testing and molecular biomarkers. 2012;16(2):95-101.

30. Watson RA. Human Papillomavirus: Confronting the Epidemic-A Urologist's Perspective. Reviews in urology. 2005;7(3):135-44.

31. Stanley M. Pathology and epidemiology of HPV infection in females. Gynecologic oncology. 2010;117(2 Suppl):S5-10.

32. Dickson EL, Vogel RI, Luo X, Downs LS. Recent trends in type-specific HPV infection rates in the United States. Epidemiology and infection. 2015;143(5):1042-7.

33. Khorasanizadeh F, Hassanloo J, Khaksar N, Mohammad Taheri S, Marzaban M, B HR, et al. Epidemiology of cervical cancer and human papilloma virus infection among Iranian women - analyses of national data and systematic review of the literature. Gynecologic oncology. 2013;128(2):27781.

34. Ghaffari SR, Sabokbar T, Mollahajian H, Dastan J, Ramezanzadeh F, Ensani F, et al. Prevalence of human papillomavirus genotypes in women with normal and abnormal cervical cytology in Iran. Asian Pacific journal of cancer prevention : APJCP. 2006;7(4):529-32.

35. Jalilvand S, Shoja Z, Nourijelyani K, Tohidi HR, Hamkar R. Meta-analysis of type-specific human papillomavirus 
prevalence in Iranian women with normal cytology, precancerous cervical lesions and invasive cervical cancer: Implications for screening and vaccination. Journal of medical virology. 2015;87(2):287-95.

36. Burd EM. Human papillomavirus and cervical cancer. Clinical microbiology reviews. 2003;16(1):1-17.

37. Coutlee F, Rouleau D, Ferenczy A, Franco E. The laboratory diagnosis of genital human papillomavirus infections. The Canadian journal of infectious diseases $\&$ medical microbiology $=$ Journal canadien des maladies infectieuses et de la microbiologie medicale / AMMI Canada. 2005;16(2):83-91.

38. Ciotti M, Coletti A, Giuliani L, Cappiello G, Syrjanen K, Favalli C. The p53 codon 72 arg/arg homozygous women in central Italy are at increased risk for HPV infections. Anticancer research. 2006;26(5B):3745-8.

39. de Sanjose S, Quint WG, Alemany L, Geraets DT, Klaustermeier JE, Lloveras $\mathrm{B}$, et al. Human papillomavirus genotype attribution in invasive cervical cancer: a retrospective cross-sectional worldwide study. The Lancet Oncology. 2010;11(11):1048-56.

40. Seoud M. Burden of human papillomavirus-related cervical disease in the extended middle East and north Africa-a comprehensive literature review. Journal of lower genital tract disease. 2012;16(2):10620.

41. Shahsiah R, Khademalhosseini M, Mehrdad N, Ramezani F, Nadji SA. Human papillomavirus genotypes in Iranian patients with cervical cancer. Pathology, research and practice. 2011;207(12):754-7.

42. De Vuyst $\mathrm{H}$, Clifford G, Li N, Franceschi S. HPV infection in Europe. European journal of cancer. 2009;45(15):2632-9.

43. Smith JS, Lindsay L, Hoots B, Keys J, Franceschi S, Winer R, et al. Human papillomavirus type distribution in invasive cervical cancer and high-grade cervical lesions: a meta-analysis update. International journal of cancer Journal international du cancer. 2007;121(3):62132.

44. Parlak M, Guducuoglu H, Bayram Y, Cikman A, Aypak C, Kilic S, et al. Identification and determination of antibiotic susceptibilities of Brucella strains isolated from patients in van, Turkey by conventional and molecular methods. International journal of medical sciences. 2013;10(10):1406-11.

45. Schneider-Stock R, Boltze C, Peters $\mathrm{B}$, Szibor R, Landt O, Meyer F, et al. Selective loss of codon 72 proline p53 and frequent mutational inactivation of the retained arginine allele in colorectal cancer. Neoplasia. 2004;6(5):529-35.

46. Farshbaf-Khalili A, SalehiPourmehr H, Shahnazi M, Yaghoubi S, Gahremani-Nasab P. Cervical cancer screening in women referred to healthcare centres in Tabriz, Iran. Nigerian medical journal : journal of the Nigeria Medical Association. 2015;56(1):28-34.

\section{How to Cite This Article:}

Sajjadi N, Mirnejad R, Sharif M, Piranfar V, Zaeifi D. Relevant Allelic Frequency of Gene Polymorphism and Genetic Predisposition of Human Papillomavirus in Patients with Cervical Cancer. Mod Med Lab J. 2018; 1 (2):50-59 